\title{
Thyroid Cancer pT2 TNM Finding v6 and v7
}

National Cancer Institute

\section{Source}

National Cancer Institute. Thyroid Cancer pT2 TNM Finding v6 and v7. NCI Thesaurus.

Code C60863.

Thyroid cancer with a tumor size greater than $2 \mathrm{~cm}$ but not more than $4 \mathrm{~cm}$ in greatest

dimension, and limited to the thyroid gland. (from AJCC 6th and 7th Eds.) 